\title{
Alfillin
}

AL-FIKRU: JURNAL PENDIDIKAN DAN SAINS, 2 (2), 2021 | e-ISSN 2774-5627 p-ISSN 2747-1349

\section{PENGGUNAAN MEDIA AUDIO-VISUAL PADA MATA PELAJARAN BAHASA ARAB}

\author{
Intan Nurhasana \\ Fakultas Tarbiyah, UIN Maulana Malik Ibrahim Malang, Indonesia \\ e-mail: intanur201@gmail.com
}

\begin{abstract}
The article with the title "The use of audio-visual media in Arabic subjects" describes the use of audio-visual media in learning. In general, Arabic learning only uses classical methods which tend to make students bored. Along with the development of the times, teachers are expected to be able to use various methods and media in the learning process. This is intended so that the learning process can take place to be more enjoyable so that the material provided can also be easily understood by students. Well-designed and creative learning by utilizing multimedia, within certain limits will be able to increase the likelihood of students to learn more to remember what they learn, better, and improve student performance in order to increase competency attainment. Media as an integral part of learning, this component needs to get the attention of teachers. The importance of media in facilitating students (learners), its presentation is adjusted to the learning objectives set. The presence of media in the learning process really helps students better understand what is being learned. Audio-visual is one of the media that can be used by teachers in learning Arabic. Moreover, with the development of technology that can make it easier for teachers and students to access and visit sites on the internet that provide information about learning Arabic.
\end{abstract}

Keywords: media, audio-visual, Arabic lessons. 


\section{PENDAHULUAN}

Pendidikan dilakukan agar peserta didik dapat mengembangkan bakat, potensi serta keterampilan yang dimiliki untuk menjalani kehidupannya, maka dari itu pendidikan perlu didesain sebaik mungkin agar dapat memberikan pemahaman dan meningkatkan prestasi belajar peserta didik. Proses mendesain pendidikan ini tidak dapat dikatakan mudah, pendidikan ini perlu didesain semenarik mungkin sebab peserta didik cenderung cepat merasa bosan dan kelelahan ketika sedang melakukan proses pembelajaran, disebabkan karena penjelasan guru yang sukar dicerna dan dipahami serta metode pembelajaran yang biasa saja.

Media merupakan alat untuk mencapai tujuan pembelajaran, dengan menerapkan media diharapkan siswa lebih mudah dalam memahami materi yang disampaikan oleh guru. Selain itu proses pembelajaran menjadi lebih menyenangkan dan siswa semakin tertarik dengan materi yang disampaikan oleh guru, sehingga tujuan pembelajaran dapat tercapai dengan maksimal.

Setiap materi pelajaran tentu memiliki tingkat kesukaran yang bervariasi. Pada satu sisi ada bahan pelajaran yang tidak memerlukan alat bantu, tetapi dilain pihak ada bahan pelajaran yang sangat memerlukan alat bantu berupa media pengajaran. Karena bahan yang tinggi sukar diproses oleh anak didik, apalagi bagi anak didik yang kurang menyukai bahan pelajaran yang disampaikan oleh guru. Maka dari itu, media sebagai alat bantu dalam proses belajar mengajar adalah suatu kenyataan yang tidak dapat dipungkiri.

Pembelajaran bahasa Arab merupakan salah satu mata pelajaran yang sulit untuk dipelajari dikarenakan siswa menghadapi problematika, baik masalah yang terkait dengan tata bunyi, kosakata, kalimat dan tulisan, serta siswa kurang mampu untuk memahami tata bahasanya, terutama dalam kajian ilmu nahwu dan sorofnya dan cara guru mengajar yang tidak dapat memahamkan peserta didiknya dengan baik juga menentukan persepsi bahasa Arab yang sulit. Oleh karena itu, dalam pengajaran bahasa Arab tentu membutuhkan media pembelajaran yang tepat dan sesuai. Hal ini dikarenakan media 
pembelajaran merupakan alat bantu dalam pembelajaran yang perlu diterapkan oleh guru agar peserta didik dalam proses pembelajaran merasa tidak bosan, dapat menarik perhatian peserta didik serta siswa dapat termotivasi sehingga tujuan pembelajaran dapat tercapai sesara aktif, kreatif, efektif, efisien dan menyenangkan. Jadi, keaktifan guru dalam menggunakan media pembelajaran merupakan salah satu kunci pembelajaran tersebut bisa dilaksanakan dengan baik atau tidak.

Media yang dapat digunakan dalam proses pembelajaran ada beragam, salah satunya yaitu audio-visual. Dalam artikel ini akan dipaparkan mengenai media audio visual, yang merupakan gabungan dari media audio dan media visual. Serta penggunaan media audiovisual dalam pembelajaran bahasa Arab.

\section{METODE}

Metode penelitian ini adalah literature review atau tinjauan pustaka yang dilakukan dengan objek media audio-visual pada mata pelajaran Bahasa Arab. Studi literature review adalah cara yang dipakai untuk megumpulkan data atau sumber yang berhubungan pada sebuah topik tertentu yang bisa didapat dari berbagai sumber seperti jurnal, buku, internet, dan pustaka lain. Literatur review adalah sebuah metode yang sistematis, eksplisit dan reprodusibel untuk melakukan identifikasi, evaluasi dan sintesis terhadap karya-karya hasil penelitian dan hasil pemikiran yang sudah dihasilkan oleh para peneliti dan praktisi. Literatur review bertujuan untuk membuat analisis dan sintesis terhadap pengetahuan yang sudah ada terkait topik yang akan diteliti untuk menemukan ruang kosong bagi penelitian yang akan dilakukan. Sumber data yang didapatkan berasal dari berbagai jurnal ilmiah nasional. Teknik pengumpulan data dengan studi dokumen, dan analisis data menggunakan metode kualitatif. 


\section{PEMBAHASAN}

\section{A. Media Pembelajaran}

Kata media berasal dari bahasa latin medius yang secara harfiah berarti tengah, perantara, atau pengantar. Dalam bahasa Arab, media adalah perantara. Pengertian media dalam proses belajar mengajar cenderung diartikan sebagai alat-alat grafis, photografis, atau elektronis untuk menangkap, memproses, dan menyusun kembali informasi visual atau verbal. Media juga dapat diartikan sebagai segala sesuatu yang dapat diindra yang berfungsi sebagai perantara atau sarana atau alat untuk proses komunikasi (proses belajar mengajar).

Media dalam arti sempit berarti komponen bahan dan komponen alat dalam sistem pembelajaran. Dalam arti luas media berarti pemanfaatan secara maksimum semua komponen sistem dan sumber belajar di atas untuk mencapai tujuan pembelajaran tertentu.

Menurut Marshall Meluhan pengertian media adalah suatu ekstensi manusia yang memungkinkannya mempengaruhi orang lain yang tidak mengadakan kontak langsung dengan dia. Media sangat membantu dalam proses belajar mengajar dan berperan penting dalam dunia pendidikan, yang mana setiap guru membutuhkan media sebagai penunjang berhasilnya penyampaian informasi yang diberikan. Pada dasarnya proses belajar mengajar adalah proses komunikasi. Dalam komunikasi sering terjadi penyimpangan-penyimpangan sehingga komunikasi tersebut tidak berjalan dengan efektif dan efisien. Maka dari itu, salah satu usaha untuk mengatasi hal tersebut dengan penggunaan media dalam proses pembelajaran.

Media merupakan alat bantu yang dapat menyambungkan interaksi antara guru dan siswa pada saat proses belajar mengajar yang mana media begitu membantu seorang guru ketika menyampaikan materi pembelajaran. Dari beberapa pendapat para ahli diatas dapat disimpulkan bahwa media merupakan alat peraga atau sarana yang digunakan untuk menyampaikan pesan dan sebagai penunjang dalam proses belajar mengajar.

Menurut Schram, media pembelajaran adalah teknologi pembawa pesan yang dapat dimanfaatkan untuk keperluan pembelajaran. Sudrajat 
juga mengutip definisi dari Briggs bahwa media pembelajaran adalah sarana fisik untuk menyampaikan isi/materi pembelajaran, misalnya buku, film, video, dan sebagainya. Suparno mengemukakan bahwa media pembelajaran adalah segala yang digunakan sebagai saluran untuk menyampaikan pesan atau informasi dari satu sumber kepada penerima pesan. Suparno menambahkan bahwa keberadaan media pembelajaran tidak selalu tergantung pada guru. Media pembelajaran tertentu dapat menyampaikan pesan dan informasi meskipun tanpa kehadiran seorang guru. Bahkan para pakar mengemukakan bahwa media pembelajaran dapat menggantikan keberadaan guru, sebagaimana yang berlangsung dalam pembelajaran terprogram dan pembelajaran jarak jauh.

Media memiliki pengertian yang sangat beragam. Hali ini dikarenakan oleh peninjauan yang dilakukan dilihat dari segi bentuk, fungsi ataupun tujuannya. Beberapa pengertian media yang disampaikan oleh para ahli, sebagai berikut:

1. Media adalah segala bentuk dan saluran yang digunakan orang untuk menyalurkan pesan/informasi (Asosiasi Teknologi dan Komunikasi Pendidikan/AECT di Amerika).

2. Media adalah sarana (prasarana) yang membantu proses pendidikan, sehingga tujuan pendidikan dapat berhasil dengan baik

3. Teknologi pembawa pesan (informasi) yang dapat dimanfaatkan untuk keperluan instruksional

4. Media adalah segala jenis komponen dalam lingkungan yang dapat merangsang untuk belajar

5. Media merupakan segala alat fisik yang dapat menyajikan pesan serta merangsang siswa untuk belajar

6. Media merupakan bentuk-bentuk komunikasi baik tercetak maupun audio visual beserta peralatannya (Asosiasi Pendidikan Nasional/NEA).

Dari pengertian diatas dapat disimpulkan bahwa media merupakan segala sesuatu yang dapat digunakan guru dalam proses pembelajaran sehingga siswa dapat terangsang untuk belajar. 
Jadi pengertian media pembelajaran secara singkat dapat dikemukakan sebagai sesuatu (bisa berupa alat, bahan, atau keadaan) yang digunakan sebagai perantara komunikasi dalam kegiatan pembelajaran. Jadi ada tiga konsep yang mendasari batasan media pembelajaran di atas yaitu konsep komunikasi, konsep sistem dan konsep pembelajaran.

Dalam proses belajar mengajar kehadiran media mempunyai arti yang cukup penting. Karena dalam kegiatan tersebut ketidakjelasan bahan yang disampaikan dapat dibantu dengan menghadirkan media sebagai perantara. Setidaknya, ada dua fungsi media dalam pembelajaran, yakni :

a. Media sebagai alat bantu

Media sebagai alat bantu dalam proses pembelajaran merupakan kenyataan yang tidak dapat dipungkiri. Karena media ini hadir untuk membantu tugas guru dalam menyampaikan materi/informasi bahan pelajaran yang akan diberikan kepada peserta didik. Sebagai alat bantu, media memiliki peran untuk mempermudah jalan menuju tercapainya tujuan pembelajaran.

b. Media sebagai sumber belajar

Sumber belajar merupakan segala sesuatu yang dapat digunakan sebagai tempat di mana bahan pengajaran itu didapatkan atau asal untuk belajar seseorang. Media sebagai sumber belajar diakui sebagai alat bantu auditif, visual, dan audiovisual. Teknologi disepakati sebagai media tidak hanya sebagai alat bantu, akan tetapi juga sebagai sumber belajar dalam proses pembelajaran.

Dalam proses pembelajaran, media pembelajaran memiliki beberapa fungsi. Beberapa fungsi tersebut dalam beberapa jenis yaitu:

1) Fungsi komunikatif.

Media pembelajaran digunakan untuk memudahkan komunikasi antara penyampai pesan dan penerima pesan.

2) Fungsi motivasi.

Dengan menggunakan media pembelajaran, diharapkan siswa akan lebih termotivasi dalam belajar. Dengan demikian, pengembangan media pembelajaran tidak hanya mengandung unsur artistik saja akan 
tetapi juga memudahkan siswa mempelajari materi pelajaran sehingga dapat meningkatkan gairah belajar siswa.

3) Fungsi kebermaknaan.

Melalui penggunaan media, pembelajaran bukan hanya dapat meningkatkan penambahan informasi berupa data dan fakta sebagai pengembangan aspek kognitif tahap rendah, akan tetapi dapat meningkatkan kemampuan siswa untuk menganalisis dan menciptasebagai aspek kognitif tahap tinggi. Bahkan lebih dari itu dapat meningkatkan aspek sikap dan keterampilan.

4) Fungsi penyamaan persepsi.

Melalui pemanfaatan media pembelajaran, diharapkan dapat menyamakan persepsi setiap siswa, sehingga setiap siswa memiliki pandangan yang sama terhadap informasi yang disuguhkan.

5) Fungsi individualitas.

Pemanfaatan media pembelajaran berfungsi untuk dapat melayani kebutuhan setiap individu yang memiliki minat dan gaya belajar yang berbeda.

Media pembelajaran ini dapat dibagi menjadi tiga, yaitu: audio, visual, dan media-visual. Media audio adalah jenis media yang dapat menyalurkan pesan-pesan ajaran berkaitan dengan indera pendengaran. Beberapa jenis media yang dapat digolongkan ke dalam media audio seperti Radio, tape recorder, piringan hitam, dan laboratorium bahasa. Media visual adalah media yang hanya mengandalkan indra penglihatan. Media visual ini ada yang menampilkan gambar diam seperti flim Strip (Film rangkai), Slide (Flim Bingkai) foto, gambar atau lukisan, dan cetakan. Ada pula media visual yang menampilkan gambar atau simbol yang bergerak seperti film bisu, film kartun. Media audiovisual adalah media yang mempunyai unsur suara dan unsur gambar. Jenis media ini mempunyai kemampuan yang lebih baik. Karena meliputi kedua jenis media yang pertama dan kedua ${ }^{1}$.

\footnotetext{
${ }^{1}$ Wina Sanjaya, 2008, Perencanaan dan desain sistem pembelajaran, Jakarta: PT. Fajar Interpratama
} 


\section{B. Media Audio-Visual}

Media Audio Visual berasal dari kata media yang berarti bentuk perantara yang digunakan oleh manusia untuk menyampaikan atau menyebar ide, gagasan, atau pendapat sehingga ide, pendapat atau gagasan yang dikemukakan itu sampai kepada penerima yang dituju. Media audio-visual merupakan media pembelajaran yang digunakan guru untuk menyampaikan materi agar diterima siswa melalui indera pendengar dan penglihat secara terpadu. Media audio-visual merupakan media yang mengkombinasikan audio dan visual atau biasa disebut media pandang-dengar. Media audio-visual kemudian dikembangkan dengan mengintegrasikan warna, kata, suara dan gambar. Dale mengatakan media Audio Visual adalah media pengajaran dan media pendidikan yang mengaktifkan mata dan telinga peserta didik dalam waktu proses belajar mengajar berlangsung. Media audio-visual yaitu jenis media yang selain mengandung unsur suara juga mengandung unsur gambar yang dapat dilihat, seperti rekaman video, berbagai ukuran film, slide suara, dan lain sebagainya. Dari pengertian ini dapat disimpulkan bahwa media audio visual adalah perantara yang dapat digunakan oleh guru dalam kegiatan belajar mengajar yang pengunaan materi penyerapannya melalui pandangan (gambar) dan pendengaran (suara).

Media pembelajaran menurut karakteristik pembangkit rangsangan indera dapat berbentuk Audio (suara), Visual (gambar), maupun Audio Visual. Pengajaran melalui audio visual jelas bercirikan pemakaian perangkat keras selama proses belajar, seperti mesin proyektor film, televisi, tape recorder dan proyektor visual yang lebar.

Kelebihan media audio visual

a. Materi yang disampaikan akan lebih jelas penjelasannya sehingga dapat lebih dipahami oleh para siswa, dan memungkinkan siswa menguasai tujuan pengajaran lebih baik.

b. Proses mengajar akan menjadi lebih bervariasi, tidak hanya komunikasi verbal, sehingga siswa tidak bosan dan guru tidak kehabisan tenaga apalagi bila guru mengajar untuk setiap jam pelajaran. 
c. Siswa akan lebih banyak melakukan kegiatan belajar, karena tidak hanya mendengarkan uraian guru, tapi juga aktifitas mengamati, melakukan, mendemonstrasikan, dan lain-lain.

d. Pengajaran akan menjadi lebih menarik sehingga dapat menumbuhkan motivasi belajar peserta didik.

Kekurangan media audio visual

a. Media audio yang lebih banyak menggunakan suara dan bahasa verbal, hanya mungkin dapat dipahami oleh pendengar yang mempunyai tingkat penguasaan kata dan bahasa yang baik.

b. Penyajian materi melalui media audio dapat menimbulkan verbalisme bagi pendengar.

c. Kurang mampu menampilkan detail dari objek yang disajikan secara sempurna.

\section{Penggunaan Media Audio-Visual Pada Pembelajaran Bahasa Arab}

Bahasa sebagai alat komunikasi merupakan salah satu sarana yang digunakan oleh manusia untuk saling berinteraksi, karena dengan bahasa manusia bisa menyampaikan ide, gagasan, perasaan, keinginan, dan menceritakan pengalamannya kepada orang lain. Selain sebagai alat komunikasi, bahasa dalam dunia pendidikan berperan sebagai pengantar pembelajaran, bahkan saat ini banyak lembaga-lembaga pendidikan yang menjadikan bahasa Asing sebagai salah satu mata pelajaran yang wajib ataupun mata pelajaran pilihan di sekolah-sekolah tertentu seperti bahasa Arab. Pembelajaran bahasa Arab disekolah mencakup empat aspek keterampilan berbahasa yaitu keterampilan berbicara, keterampilan mendengarkan, keterampilan membaca, dan keterampiln menulis. Sebagai upaya untuk mempermudah proses pembelajaran Bahasa Arab guru dapat menggunakan media berupa 
audio-visual. Susilana dan Riyana ${ }^{2}$ mengungkapkan bahwa penggunaan media berbasis audio visual pada dasarnya merupakan pembelajaran yang diharapkan mampu mempermudah penyajian materi pembelajaran, meningkatkan motivasi belajar siswa dan mengatasi keterbatasan ruang dan waktu peserta didik.

Proses belajar mengajar merupakan kegiatan yang bertujuan untuk mencapai perkembangan optimal, meliputi aspek kognitif, afektif, dan psikomotorik. Salah satu unsur yang mendukung dalam pencapaian pembelajaran adalah evektifitas penggunaan media secara integrasi dalam proses belajar mengajar dan materi yang diajarkan.

Penggunaan media audiovisual sangat efektif dalam membangkitkan motivasi serta memberikan kesan yang menarik dalam proses pembelajaran, membangkitkan minat, memperjelas masalah/materi yang sedang dibahas, serta membangun komunikasi aktif yang tidak hanya terjadi antara guru dan peserta didik, namun antar peserta didik yang dapat berfungsi sebagai sumber belajar bagi satu sama lain.

Pengguaan media audiovisual dalam pembelajaran bahasa Arab, menjadikan peserta didik lebih fokus serta tidak mudah merasa bosan dan cepat memahami materi yang diajarkan, ditunjang dengan perencanaan yang baik, termasuk dengan keterampilan mendesain materi yang akan diajarkan dengan penggunaan media yang efektif, karena hal tersebut memiliki peran yang penting dalam menarik minat peserta didik.

Penggunaan media audio-visual dianggap tepat dan efektif untuk memberikan pemahaman serta mempermudah peserta didik dalam menyerap materi yang disampaikan. Evektifitas pembelajaran yang dimaksud merujuk pada seberapa efektif program pembelajaran

2 Rizcha Amalia Putri, Muhammad Hanif, dan Dzulfikar Rodafi, 2020, "Strategi Pembelajaran Bahasa Arab Dalam Menggunakan Media Audio-Visual Guna Meningkatkan Daya Ingat Peserta Didik Di Sekolah", Jurnal Pendidikan Islam Volume 5 Nomor 4 Tahun 2020 P-Issn: 2087-0678x 
membantu peserta didik dalam penguasaan misalnya tata bahasa atau kosa kata. Misalnya, materi keterampilan berbicara (maharatul kalam) merupakan salah satu materi yang diajarkan dengan penggunaan audiovisual, peserta didik dilatih melalui proses belajar dan latihan secara berkesinambungan dan sistematis agar dapat memperlancar komunikasi secara langsung. Penggunaan media audio-visual dilakukan tidak lain untuk meningkatkan kualitas dan kemampuan peserta didik terhadap keterampilan bebahasa, baik keterampilan membaca, berbicara, menulis dan mendengar. Selain itu, peserta didik membutuhkan metode mengajar yang tidak monoton, pembelajaran penggunaan audiovisual juga membantu mengkomunikasikan materi yang diajarkan.

Salah satu contoh penggunaan media audio-visual dalam proses pembelajaran Bahasa Arab adalah dengan menggunkan film. Guru dapat menyiapkan film yang memiliki pesan tersirat yang baik dalam menggunakan Bahasa Arab, sehingga peserta didik tidak hanya belajar mendengar perbincangan menggunakan Bahasa Arab tetpai juga mendapat pesan dari film yang disampaikan. Menggunakan media film ini dapat membuat peserta didik menjadi lebih semangat dalam proses pembelajaran, selain itu juga peserta didik dapat menambah kosa kata baru berbahasa Arab beserta kaidah pengucapannya. Sehingga kompetensi mendengar (istima') dan juga berbicara (kalam) dapat tercapai sekaligus.

Selain itu media audio visual dalam pembelajaran Bahasa Arab yang dapat digunakan salah satunya adalah laboratorium bahasa dengan menggunakan berbagai metode yang menarik, LCD yang digunakan untuk menampilkan gambar dan suara. Selain itu, situs internet juga merupakan media yang paling mudah dijangkau. Untuk pembelajaran bahasa Arab ini pemula dapat dengan intensif belajar diluar kelas dengan mengikuti pembelajaran di sebuah situs internet, tidak hanya dalam pembelajaran kosakata, melainkan dalam keterampilanketerampilan bahasa lainnya.

Pengimplementasian media audio-visual dalam kegiatan belajar mengajar dapat menjadikan kegiatan belajar mengajar menjadi lebih menarik dan mempermudah peserta didik untuk memahami suatu 
materi dan dapat meningkatkan daya ingat peserta didik. Dengan diterapkannya media pembelajaran audio dan visual guru mengharapkan peserta didik lebih memahami materi yang telah di ajarkan sehingga dengan mudah melekat di ingatan peserta didik. Karena dengan belajar menerapkan media audio dan visual maka peserta didik dapat melatih semua panca inderanya sehingga otak lebih bekerja dan tidak ada rasa bosan dalam kegiatan belajar mengajar.

Dalam pengimplementasi suatu materi dengan menggunakan media audio-visual, maka seorang guru memberikan materi dengan menggunakan power point, vidio pembelajaran bahasa arab, serta nyanyian yang ditayangkan menggunakan LCD proyektor yang telah disediakan dari sekolah. Sebagai guru yang profesional harus bisa mengimplementasikan media dengan tepat. Karena jika tidak bisa mengelola media pembelajaran dengan tepat maka akan terjadi konfrontasi di kelas.

\section{PENUTUP}

Berdasarkan penjelasan-penjalasan di atas, maka dapat disimpulkan bahwa media pembelajaran merupakan segala yang digunakan sebagai perantara untuk menyampaikan pesan atau informasi pada proses pemebelajaran. Dalam proses belajar mengajar kehadiran media memiliki peran yang cukup penting, sebab dalam kegiatan ini media dapat digunakan sebagai perantara untuk menyampaikan bahan ajar yang sulit untuk dijelaskan. Kerumitan bahan ajar yang akan disampaikan kepada peserta didik dapat disederhanakan dan dibantu dengan kehadiran media. Media audiovisual merupakan media pembelajaran yang digunakan guru untuk menyampaikan materi agar diterima siswa melalui indera pendengar dan penglihat secara terpadu. Penggunaan medai audio-visual harus dibarengi dengan kompetensi guru dalam mengelola serta membuat strategi pembelajaran yang baik, agar peran media sebgaai alat bantu ajar dapat tersampaikan sehingga tujuan dati pembelajaran dapat tercapai secara efektif dan efisien. 


\section{DAFTAR PUSTAKA}

Ahmad Rohani, Media Instruksional Edukatif, (Jakarta: PT Rineka Cipta,1997)

Azhar Arsyad, Media Pembelajaran, cet.6, (Jakarta: PT. Raja Grafindo Persada, 2005

Harjanto, 2006, Perencanaan Pengajaran cet.2, Jakarta : Rineka Cipta Imam Asrori, 2015, Media Pembelajaran Bahasa Arab, Malang: CV Bintang Sejahtera

M. Miftah, 2013, "Fungsi Dan Peranan Media Pembelajaran Sebagai Upaya Peningkatan Kemampuan Belajar Siswa", dalam Jurnal Teknologi Pendidikan Kwangsan Oleh Balai pengembagan Media Televisi Pendidikan Kementrian Pendidikan dan kebudayaan

Rizqi Ilyasa Aghni, 2018, "Fungsi Dan Jenis Media Pembelajaran Dalam Pembelajaran", Jurnal Pendidikan Akuntansi Indonesia, Vol. XVI, No. 1

Rizcha Amalia Putri, Muhammad Hanif, dan Dzulfikar Rodafi, 2020, "Strategi Pembelajaran Bahasa Arab Dalam Menggunakan Media Audio-Visual Guna Meningkatkan Daya Ingat Peserta Didik Di Sekolah", Jurnal Pendidikan Islam Volume 5 Nomor 4 Tahun 2020 PIssn: 2087-0678x

Wina Sanjaya, 2008, Perencanaan dan desain sistem pembelajaran, Jakarta: PT. Fajar Interpratama 